\title{
Stephania delavayi Diels. inhibits breast carcinoma proliferation through the p38 MAPK/NF-кB/COX-2 pathway
}

\author{
DAE-HUN PARK ${ }^{1 *}$, HONG DE XU ${ }^{2 *}$, JAEGAL SHIM $^{3 *}$, YONG-CHUN LI $^{4}$, JONG-HWA LEE ${ }^{1}$, \\ SOON-CHANG CHO ${ }^{5}$, SANG-SEOP HAN ${ }^{6}$, YUN LYUL LEE ${ }^{7}$, MIN-JAE LEE ${ }^{4}$ and SUNG-WON KWON $^{8}$ \\ ${ }^{1}$ Toxicology Center, Korea Institute of Toxicology, Yuseong, Daejeon 305-343, Republic of Korea; ${ }^{2}$ School of \\ Pharmaceutical Science, Zhengzhou University, Zhengzhou 4500001, P.R. China; ${ }^{3}$ Cancer Experimental Resources \\ Branch, National Cancer Center, Ilsandong-gu, Goyang-si, Gyeonggi-do 410-769; ${ }^{4}$ School of Veterinary Medicine, \\ Kangwon National University, Chuncheon-si, Gangwon-do 200-701; ${ }^{5}$ Center for Senior Industry, Youngdong \\ University, Yeongdong-gun, Chungnam 370-701; ${ }^{6}$ Hoseo University, Baebang-myun, Asan-si, Chungnam 336-79; \\ ${ }^{7}$ Department of Physiology, College of Medicine, Hallym University, Chuncheon-si, Gangwon-do, 200-70; ${ }^{8} \mathrm{CHA}$ \\ Bundang Medical Center, CHA University, Bundang-gu, Seongnam-si, Gyeonggi-do 463-712, Republic of Korea
}

Received March 4, 2011; Accepted April 20, 2011

DOI: $10.3892 /$ or.2011.1364

\begin{abstract}
The nuclear factor $\kappa \mathrm{B}(\mathrm{NF}-\kappa \mathrm{B}) /$ inhibitor of $\kappa$ kinase- $\beta$ (IKK $\beta$ ) signaling pathway is important in tumor promotion and progression. MDA-MB-231 human breast carcinoma cells express COX-2 and show a constitutive phosphorylation of NF- $\kappa \mathrm{B}$. Many non-specific inhibitors of IKK $\beta$ and $N F-\kappa B$ are used to inhibit tumor promotion and progression. The Stephania delavayi Diels. (S. delavayi Diels.) extract has been reported to safely activate B cell immunity and there is evidence suggesting that it may be a promising new anticancer therapeutic agent. S. delavayi Diels. extract suppressed proliferation of the breast cancer cell lines MDA-MB-231 and MCF-7 by inducing cell death. To aid in the development of the $S$. delavayi Diels. extract as a therapeutic agent, its mechanisms of action were investigated, in particular its effects on p38 MAPK, NF- $\mathrm{B}$ and COX-2, which play important roles in inflammation and cancer. $S$. delavayi Diels. stimulated p38 MAPK phosphorylation but reduced NF- $\kappa \mathrm{B}$ phosphorylation and COX-2 expression in a dose- and timedependent manner. Thus, S. delavayi Diels., which appears to
\end{abstract}

Correspondence to: Dr Min-Jae Lee, School of Veterinary Medicine, Kangwon National University, Chuncheon-si, Gangwon-do 200-701, Republic of Korea

E-mail:mjlee@kangwon.ac.kr

Dr Sung-Won Kwon, CHA Bundang Medical Center, CHA University, Bundang-gu, Seongnam-si, Gyeonggi-do 463-712, Republic of Korea E-mail: wizard95@cha.ac.kr

*Contributed equally

Key words: Stephania delavayi Diels., breast carcinomas, apoptosis, nuclear factor $\kappa \mathrm{B}, \mathrm{COX}-2$ act primarily through p38 MAPK/NF- $\mathrm{B} / \mathrm{COX}-2$ signaling in breast carcinomas, may be a potent anticancer agent with target specificity and low toxicity.

\section{Introduction}

MAPKs play key roles in mediating the effects of various extracellular stimuli and intracellular responses. Three MAPKs have been identified in mammalian cells: ERKs, JNKs, and p38 kinase (p38 MAPK). Each MAPK is activated by different stimuli and regulates different downstream targets (1). In particular, p38 MAPK is stimulated by UV irradiation, osmotic stress, and cytokines such as tumor necrosis factor- $\alpha$ (TNF- $\alpha$ ) and interleukin-1 $\beta$ (IL-1 $\beta)(1,2)$.

The nuclear factor $\kappa \mathrm{B}(\mathrm{NF}-\kappa \mathrm{B}) /$ inhibitor of $\kappa$ kinase $-\beta$ $(\operatorname{IKK} \beta)$ signaling pathway is important in tumor promotion and progression (3). When activated, the transcription factor $\mathrm{NF}-\kappa \mathrm{B}$ inhibits apoptosis (4), induces G1/S phase transition by up-regulating the expression of cyclin D1 (5) and COX-2 (6). In MDA-MB-231 human breast carcinoma cells, NF- $\kappa \mathrm{B}$ and inhibitor of $\kappa \mathrm{B}(\mathrm{I} \kappa \mathrm{B})$ are constitutively phosphorylated (7) and COX-2 expression is observed (8). Many non-specific inhibitors of IKK $\beta$ and $\mathrm{NF}-\kappa \mathrm{B}$ are used to inhibit tumor promotion and progression. These agents include anti-inflammatory drugs, such as sulphasalazine and trans-resveratrol, and non-steroidal anti-inflammatory drugs, such as aspirin, sulindac sulphide, cyclopentenone prostaglandins, proteasome inhibitors, and glucocorticoids (9-11). Similarly, COX-2 inhibitors have also been used to slow the progression of cancer $(12,13)$.

Species of the Stephania family are known to exert pharmacological actions. For example, the Stephania delavayi Diels. ( $S$. delavayi Diels.) extract has been reported to safely activate B cell immunity (14), and biscoclaurine alkaloid cepharanthine isolated from Stephania cepharantha Hayata (S. cepharantha Hayata) induces apoptosis and $\mathrm{G}_{0} / \mathrm{G}_{1}$ phase arrest through $\mathrm{p} 15^{\mathrm{INK} 4 \mathrm{~B}}$ and $\mathrm{p} 21^{\text {Waf1/Cip1 }}$ in KMS-12-PE myeloma cells (15). Tetrandrine, a bisbenzylisoquinoline alkaloid isolated 
from the root of Stephania tetrandra S. Moore (S. tetrandra $\mathrm{S}$. Moore), induces $\mathrm{G}_{1}$ arrest in human colon carcinoma HT29 cells by down-regulating E2F1 and up-regulating p53/p21 Waf1/Cip1 (16). In addition, the bisbenzylisoquinoline alkaloids cepharanthine, berbamine, and isotetrandrine isolated from $S$. cepharantha Hayata inhibit arachidonic acid-induced inflammation in mice (17).

S. delavayi Diels. is a promising new anticancer therapeutic agent candidate. This herb has been used in traditional Chinese medicine to relieve pain and treat acute gastroenteritis. In addition, $S$. delavayi Diels. is a component of a herbal mixture PC-SPES, which has been used to treat prostate cancer via its estrogenic mechanism of action (18) and has been shown to inhibit MCF-7 cell proliferation by inducing apoptosis and cell cycle arrest (19). However, the molecular mechanisms underlying the $S$. delavayi Diels. anticancer properties have not yet been elucidated.

In the present study, we evaluated the effects of $S$. delavayi Diels. on NF- $\mathrm{NB}$ and COX-2 in breast carcinomas. In an effort to elucidate the molecular and functional basis of its antiinflammatory and anticancer effects, we found that S. delavayi Diels. promotes apoptosis by activating p38 MAPK and inhibiting $\mathrm{NF}-\kappa \mathrm{B}$ phosphorylation and COX-2 expression. Our findings provide additional evidence in support of a future use for $S$. delavayi Diels. as a preventative or therapeutic agent against breast cancer.

\section{Materials and methods}

Preparation of S. delavayi Diels. extract. S. delavayi Diels. extract, which was acquired from the International Biological Material Research Center (Daejeon, Korea), was collected on Mt. Bijia, Anning, Yunnan, China.

Standardization of S. delavayi Diels. was performed by thin layer chromatography (Polygram ${ }^{\circledR}$ Sil G/UV254, 20 x $20 \mathrm{~cm}$, $0.2 \mathrm{~mm}$ thick; Macherey-Nagel GmbH \& Co. KG, Düren, Germany) with the eluent methylene chloride/methanol/ $\mathrm{H}_{2} \mathrm{O}$ (70:27:3). Analytical HPLC was performed using a Waters 2695 Separations Module system (Waters Corp., MA, USA) with the Waters photodiode array detector 2996 (variable wavelength UV) and a C18 column (YMC-Pack Pro, C18, S-5 $\mu \mathrm{m}, 12$ nm, 4.6 i.d. x 250 mm; YMC Co., Ltd., Kyoto, Japan). We used a gradient elution of $0.05 \%$ trifluoroacetic acid in acetonitrile $/ 0.05 \%$ trifluoroacetic acid in $\mathrm{H}_{2} \mathrm{O}$ at a flow rate of $0.7 \mathrm{ml} / \mathrm{min}(10-40 \%$ aqueous acetonitrile, $60 \mathrm{~min})$. Each fraction was examined for alkaloids with Dragendorff reagent.

Cell culture. The human breast cancer cell lines MDA-MB231 and MCF-7 were obtained from the Korean Cell Line Bank (Seoul, Korea). Cells were cultivated in RPMI-1640 containing $10 \%$ fetal bovine serum, $2 \mathrm{mg} / \mathrm{ml}$ sodium bicarbonate, $100 \mathrm{U} / \mathrm{ml}$ penicillin, and $100 \mu \mathrm{g} / \mathrm{ml}$ streptomycin (Gibco-BRL, NY, USA).

Cell viability assay. Cells were seeded in 96-well plates $\left(1.5 \times 10^{4}\right.$ cells/well $)$ in triplicate and treated with $1,2,4,8$, or $16 \mu \mathrm{g} / \mathrm{ml} \mathrm{S}$. delavayi Diels. $12-24 \mathrm{~h}$ after plating; control cells were treated with the $0.1 \%$ DMSO vehicle alone. Cell proliferation was analyzed 24 and $48 \mathrm{~h}$ later using the CCK- 8 cell counting kit (Dojindo Molecular Technologies, Inc., Tokyo, Japan) according to the manufacturer's instructions.

Chemosensitivity assay. The chemosensitivity assay was performed using the CytoSelect ${ }^{\mathrm{TM}}$ 96-well in vitro tumor sensitivity assay (Cell Biolabs, Inc., CA, USA) according to the manufacturer's protocol.

Apoptosis detection by Annexin V staining. Cells were treated with $4-50 \mu \mathrm{g} / \mathrm{ml} S$. delavayi Diels. $24 \mathrm{~h}$ after plating. After incubation for 24 or $48 \mathrm{~h}$, cells were harvested, washed, and resuspended. FITC-conjugated Annexin V and propidium iodide (PI) $5 \mu \mathrm{l}$ each, were added to the cells, followed by addition of binding buffer, and the Annexin V-stained cells were analyzed with BD FACScan (Becton-Dickinson, NJ, USA).

Protein extraction and Western blot analysis. Harvested cells were washed, and total proteins were prepared with the PRO-PREP ${ }^{\text {TM }}$ protein extraction kit (iNtRON Biotechnology, Seongnam, Korea). Equal amounts of protein were loaded, separated by $10 \%$ SDS and then transferred to a nitrocellulose membrane in Trans-Blot ${ }^{\circledR}$ Transfer Medium (Bio-Rad). Proteins were detected with the following primary anitbodies: phospho-p38 MAPK (Cell Signaling Technology, Inc., MA, USA, cat \#9215), phospho-SAPK/JNK (Cell Signaling Technology, Inc., cat \#9251), phospho-AKT (Cell Signaling Technology, Inc., cat \#4060 and cat \#2965), NF-кB (Cell Signaling Technology, Inc., cat \#4764), COX-2 (Cayman Chemical, MI, USA, cat \#CAY-160106), $\beta$-actin (Sigma-Aldrich, MO, USA; cat \#A-5316). A horseradish peroxidase-conjugated goat anti-rabbit IgG (Cayman Chemical, cat \#10004301) was used as the secondary Ab. Antobody-stained bands were analyzed using the ECL detection kit (Amersham Biosciences, Buckinghamshire, UK).

Fast activated cell-based enzyme-linked immunosorbent assay. Phosphorylation of NF- $\mathrm{B}$ in each cell which was incubated with $4-8 \mu \mathrm{g} / \mathrm{ml} S$. delavayi Diels. for 1 or $3 \mathrm{~h}$ was determined using the $\mathrm{FACE}^{\mathrm{TM}} \mathrm{NF}-\kappa \mathrm{B}$ p65 Profiler (Active Motif, CA, USA) according to the manufacturer's protocol.

$N F-\kappa B$ translocation assay. Attached cells were treated with $S$. delavayi Diels. (4 $\mu \mathrm{g} / \mathrm{ml}$ for MDA-MB-231 cells; $5 \mu \mathrm{g} / \mathrm{ml}$ for MCF-7 cells) or vehicle alone and incubated for 1 or $3 \mathrm{~h}$ in a Lab-Tek ${ }^{\circledR}$ II Chamber Slide ${ }^{\mathrm{TM}}$ System (Nalge Nunc International, NY, USA). Cells were washed twice in cold PBS, fixed with cold acetone, and washed again three times in PBS. The fixed cells were incubated overnight with antiNF- $\kappa$ B rabbit antibody (Cell Signaling Technology, Inc.), followed by two washes in PBS. Cells were then incubated for $1 \mathrm{~h}$ with goat anti-rabbit IgG FITC (Cayman Chemical) followed by $7 \mu \mathrm{g} / \mathrm{ml}$ bisbenzimide $\mathrm{H} 33342$ trihydrochloride (Sigma-Aldrich) for nuclear staining, and photographed using an LSM 510 Meta Fluorescent Microscope with PlanApochromat 100x/1.4 Oil DIC (Carl Zeiss, Jena, Germany).

Immunocytochemical detection of $C O X-2$. After treatment with $S$. delavayi Diels. or vehicle alone, attached cells were incubated for 24 or $48 \mathrm{~h}$ in a Lab-Tek II Chamber Slide system. 


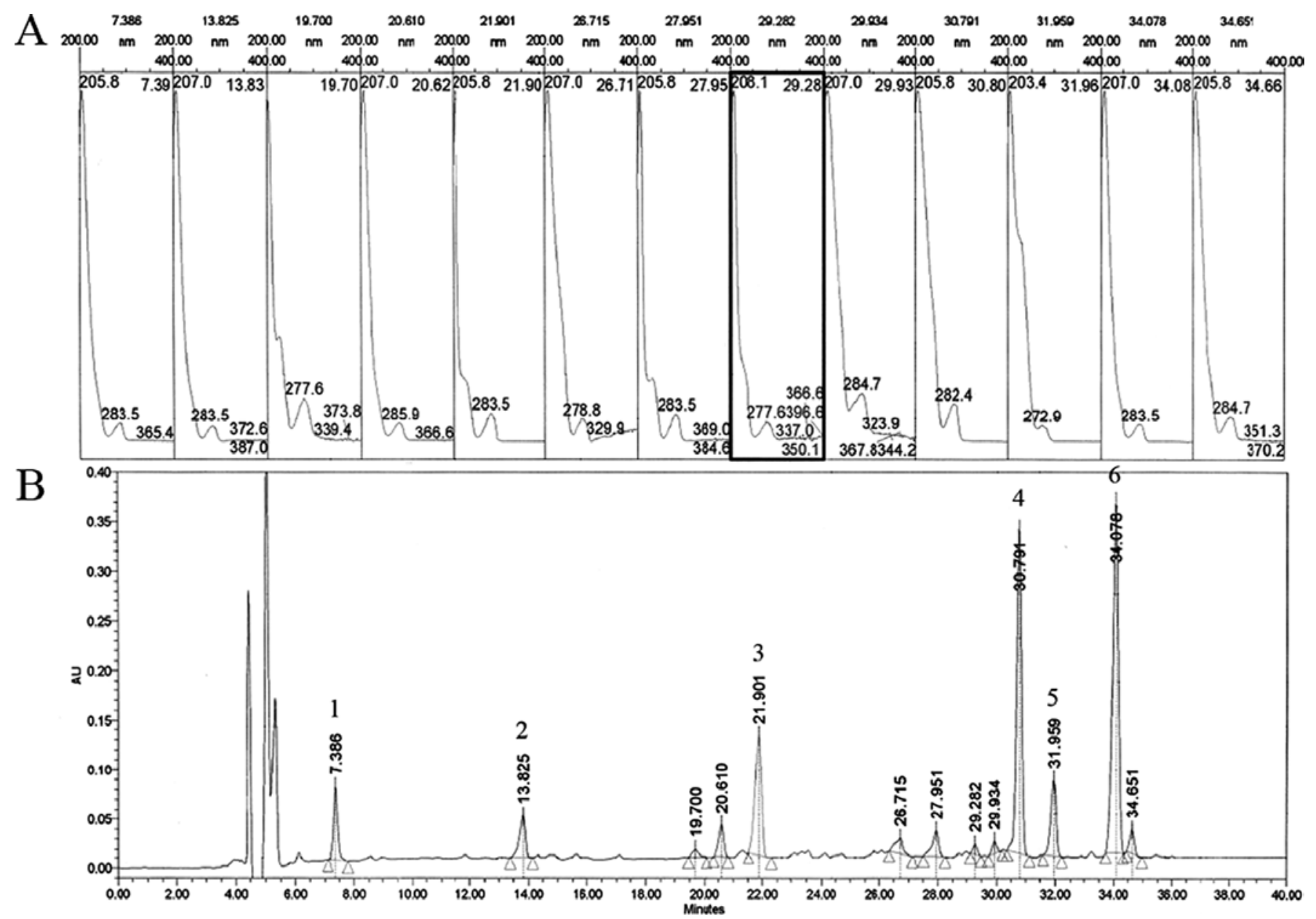

Figure 1. Fingerprint profiles of Stephania delavayi Diel. extracts. The UV spectra (A) and chromatogram (B) of typical compounds in peak group 1-6 are shown at upside. HPLC conditions, YMC-Pack Pro C18 column ( 4.6 × $250 \mathrm{~mm}, 5 \mu \mathrm{m})$. Mobile phases were of $0.05 \%$ trifluoroacetic acid in acetonitrile and $0.05 \%$ trifluoroacetic acid in water with gradient elution as $10-40 \%$ aqueous acetonitrile at a flow rate of $0.7 \mathrm{ml} / \mathrm{min}$, wavelength, $200-400 \mathrm{~nm}$.

Cells were washed twice in cold PBS, fixed with cold acetone, and washed again three times in PBS. Fixed cells were incubated overnight with anti-COX-2 monoclonal antibody (Biocare Medical, CA, USA), followed by two washes in PBS. Cells were reacted with EnVision ${ }^{\mathrm{TM}}+$ reagent (Dako, Glostrup, Denmark), developed with the Liquid DAB substrate chromogen system (Dako), counterstained, and photographed using Axio Observer A1 (Carl Zeiss).

Human tumor xenografts. Thirty-one 8-week-old female Crl:NU/NU-nu mice were purchased from OrientBio (Seongnam, Korea) and acclimated for 7 days in an environment controlled for temperature and relative humidity $\left(22 \pm 3^{\circ} \mathrm{C}\right.$, 12-h light/dark cycle). The mice were provided a Purina diet (Seongnam, Korea) and water ad libitum. After acclimation, the mice were subcutaneously injected with $5 \times 10^{6}$ MDA-MB231 cells into each flank. When the tumor volume reached $100-150 \mathrm{~mm}^{3}$, mice were randomly assigned to one of four treatment groups. The first group (control; $n=7$ ) received the $0.1 \%$ DMSO vehicle. The second group $(\mathrm{n}=8)$ received $10 \mathrm{mg} / \mathrm{kg}$ paclitaxel by intraperitoneal injection once per week (SigmaAldrich); the third group $(\mathrm{n}=8)$ received daily $10 \mathrm{mg} / \mathrm{kg}$ intraperitoneal injections of $S$. delavayi Diels., and the fourth group $(\mathrm{n}=8)$ received both $10 \mathrm{mg} / \mathrm{kg}$ paclitaxel once a week and $10 \mathrm{mg} / \mathrm{kg}$ S. delavayi Diels. daily intraperitoneally. During the 24-day treatment period, tumors were measured with a caliper in two dimensions every 3 days; tumor volumes were calculated as $\mathrm{axb}^{2} / 2$, where a was the widest point of the tumor and $b$ was the tumor width perpendicular to $a$. The human tumor xenograft study had been approved by the Institute of Animal Care and Use Committee of the Kangwon National University before performing the experiments.

Statistical analysis. Results are expressed as the mean \pm SD. Groups were compared using the Tukey's studentized range (HSD) test; $\mathrm{p}<0.01$ was considered significant.

\section{Results}

S. delavayi Diels. extract effectively inhibits breast cancer cell proliferation. To confirm the quality of the $S$. delavayi Diels., the extracts ( 6 batches) used in each experiment were analyzed by the HPLC-DAD method (Fig. 1). Mean retention times of the six characteristic peaks were 7.386, 13.825, 21.901, 30.791, 31.959 and $34.078 \mathrm{~min}$. HPLC chromatogram analysis showed that the maximum UV light absorbance of each peak was similar and each fraction reacted with Dragendorff reagent, suggesting that the properties of the $S$. delavayi Diels. extracts 

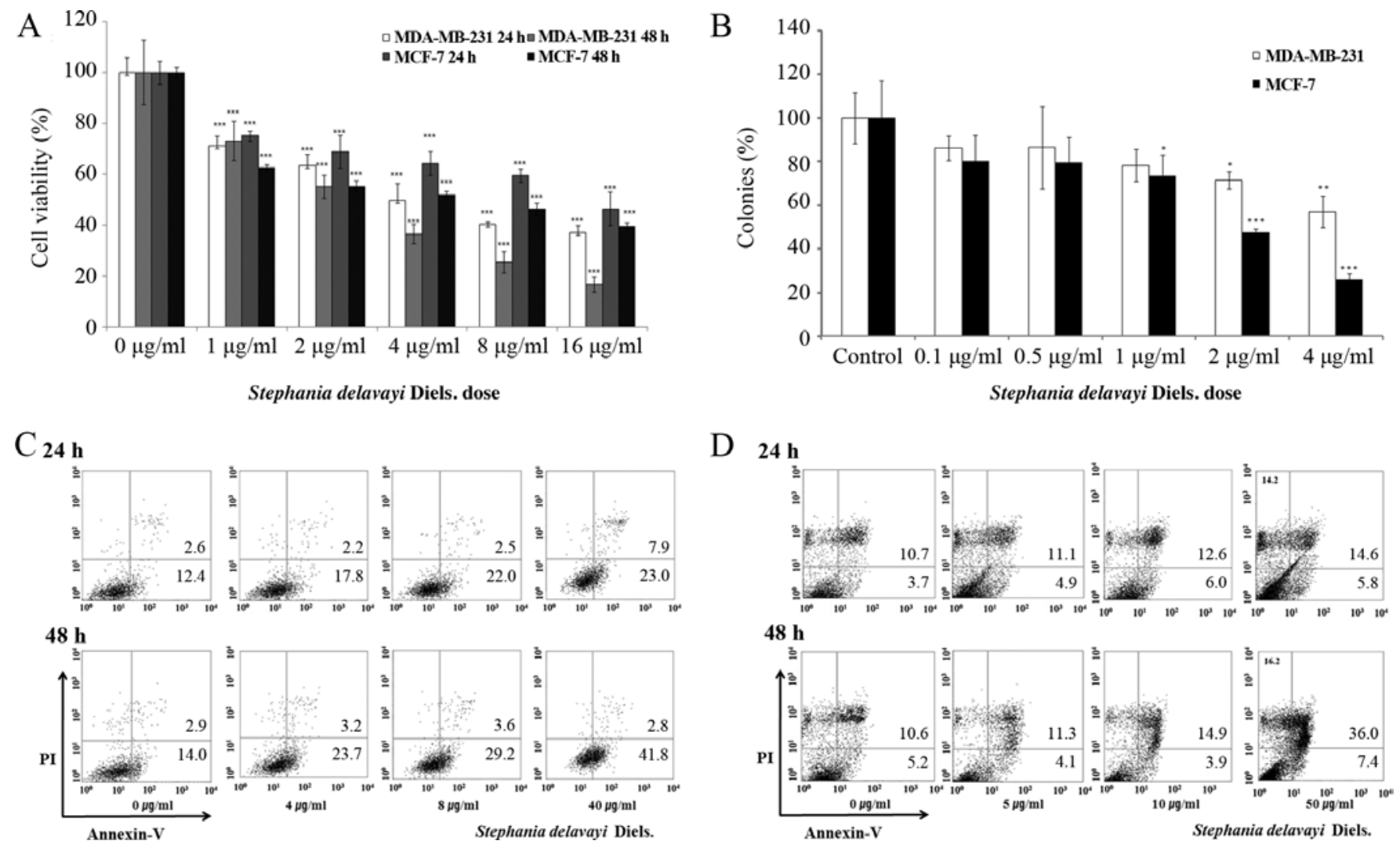

Figure 2. Inhibition of breast carcinoma cell proliferation by Stephania delavayi Diels. (S. delavayi Diels.) (A) S. delavayi Diels. inhibits proliferation of MDA-MB-231 and MCF-7 cells in a dose- and time-dependent manner. (B) S. delavayi Diels. inhibits colony formation of MDA-MB-231 and MCF-7 cells. (C) S. delavayi Diels. induces cell death in MDA-MB-231 cells. Apoptotic cells increased in a time- and dose-dependent manner in MDA-MB-231 cells. At $24 \mathrm{~h}$, control cells exhibited $15.0 \%$ apoptosis, and cells treated with 4 and $40 \mu \mathrm{g} / \mathrm{ml} \mathrm{S}$. delavayi Diels. exhibited an increase in apoptosis up to 20.0 and $30.9 \%$, respectively. The population of apoptotic cells reached $44.6 \%$ after $48-\mathrm{h}$ treatment with $40 \mu \mathrm{g} / \mathrm{ml}$ S. delavayi Diels. (D) S. delavayi Diels. induces cell death in MCF-7. Apoptotic cells increased in a time- and dose-dependent manner in the MCF-7 cell line. At $24 \mathrm{~h}$, control cells exhibited 14.4\% apoptosis and cells treated with 5 and $50 \mu \mathrm{g} / \mathrm{ml}$ S. delavayi Diels. exhibited an increase in apoptosis up to 16.0 and $20.4 \%$, respectively. The population of apoptotic cells reached 43.4\% in MCF-7 cells after 48-h treatment with $50 \mu \mathrm{g} / \mathrm{ml}$ S. delavayi Diels.

used in each experiment were identical and HPLC-DAD facilitates the determination of the chemical constituents of $S$. delavayi Diels. samples.

To evaluate the anticancer therapeutic potential of S. delavayi Diels., we treated cells with increasing doses of $S$. delavayi Diels. and observed cell proliferation at various time points. We found that $S$. delavayi Diels. inhibited cell proliferation in a dose- and time-dependent manner (Fig. 2A and B). At 48 h, the half maximal inhibitory concentration $\left(\mathrm{IC}_{50}\right)$ was $\sim 4 \mu \mathrm{g} / \mathrm{ml}$ for MDA-MB-231 cells and $5 \mu \mathrm{g} / \mathrm{ml}$ for MCF-7 cells.

To characterize the mechanism underlying the inhibition of cell proliferation, flow cytometry was used to monitor apoptosis in MDA-MB-231 and MCF-7 cells stained with PI and Annexin V-FITC. Treatment with $S$. delavayi Diels. dramatically increased the number of Annexin V-stained and $\mathrm{PI} /$ Annexin V-stained cells in a dose- and time-dependent manner (Fig. 2C and D). At $24 \mathrm{~h}$, apoptosis in cells treated with 4 and $40 \mu \mathrm{g} / \mathrm{ml} S$. delavayi Diels. was increased to 20.0 and $30.9 \%$ in MDA-MB-231 cells, while with 5 and $50 \mu \mathrm{g} / \mathrm{ml}$ apoptosis was increased to 16.0 and $20.4 \%$ in MCF-7 cells, respectively. In contrast, apoptosis in control cells was $15.0 \%$ (MDA-MB-231) and 14.4\% (MCF-7). Apoptosis was highest after a 48 -h treatment with 40 or $50 \mu \mathrm{g} / \mathrm{ml}$ S. delavayi Diels. (MDA-MB-231, 44.6\%; MCF-7, 43.4\%). The $\mathrm{IC}_{50}$ of paclitaxel at
$72 \mathrm{~h}$ for MDA-MB-231 cells has been reported as 1-0.01 $\mu \mathrm{g} / \mathrm{ml}$, and $27 \%$ of the cells were apoptotic at $24 \mathrm{~h} \mathrm{(20)}$; the $\mathrm{IC}_{50}$ of paclitaxel at $48 \mathrm{~h}$ for MCF-7 cells was reported as $0.24 \mu \mathrm{g} / \mathrm{ml}$ (21). Thus, the apoptotic effects of $S$. delavayi Diels. in MDA-MB-231 and MCF-7 cells is similar to that of paclitaxel, suggesting the potential of $S$. delavayi Diels. as an anticancer drug candidate.

S. delavayi Diels. inactivates $N F-\kappa B$ through p38 MAPK phosphorylation. $\mathrm{NF}-\kappa \mathrm{B}$, a well-known survival factor in cancer cells, transcriptionally regulates COX-2 expression (22), and is regulated in turn by $\mathrm{p} 38$ MAPK $(2,23,24)$. We evaluated the effect of $S$. delavayi Diels. on p38 MAPK phosphorylation by Western blot analysis, and determined the effect on $\mathrm{NF}-\kappa \mathrm{B}$ activity in MDA-MB-231 cells using an in-cell immunosorbent assay that calculates the ratio of phosphorylated NF- $\mathrm{B}$ (Ser486) to total $\mathrm{NF}-\kappa \mathrm{B}$.

We examined the effect of $S$. delavayi Diels. on important regulators of programmed cell death, including phospho-Akt (Ser473 and Thr308), the MAPK pathway (phospho-p38 MAPK and phospho-JNK), and their downstream target NF- $\mathrm{B}$ (phospho-NF-кB). We found that $S$. delavayi Diels. treatment induced p38 MAPK phosphorylation but did not alter Akt and JNK phosphorylation (data not shown). Phosphorylation of p38 
A
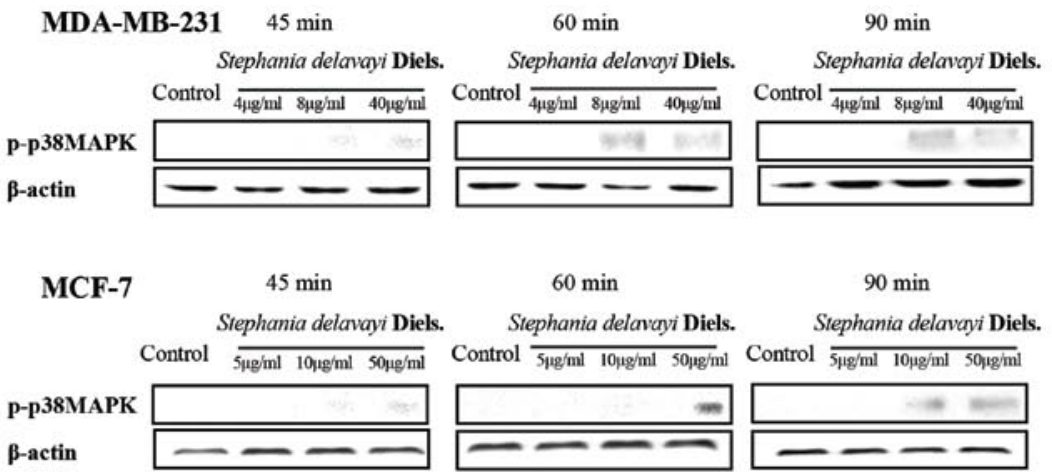

B

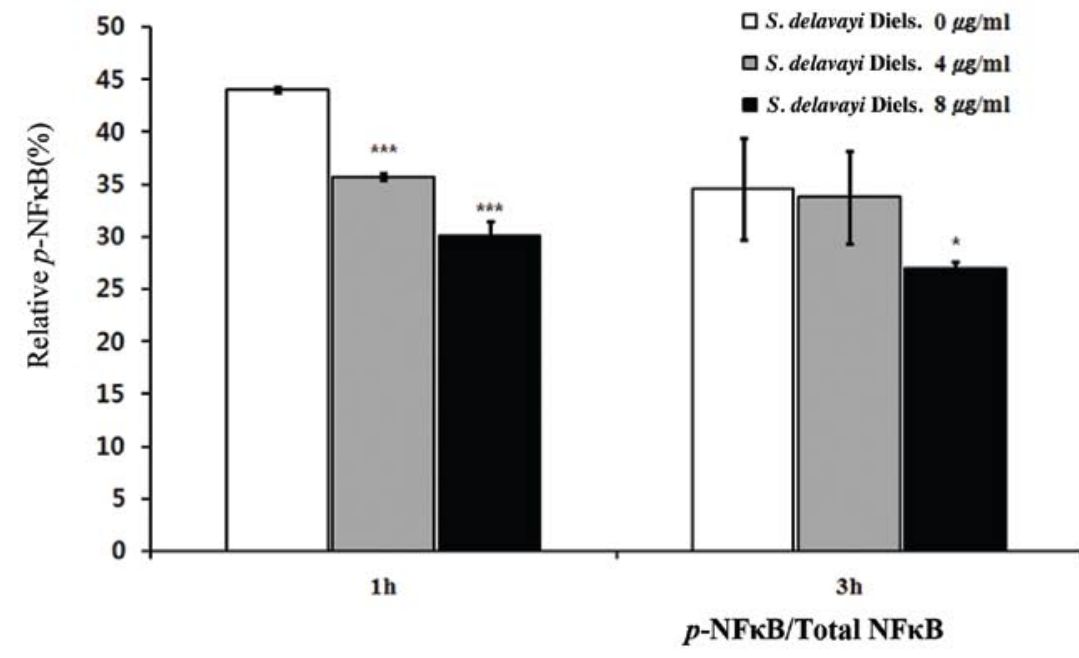

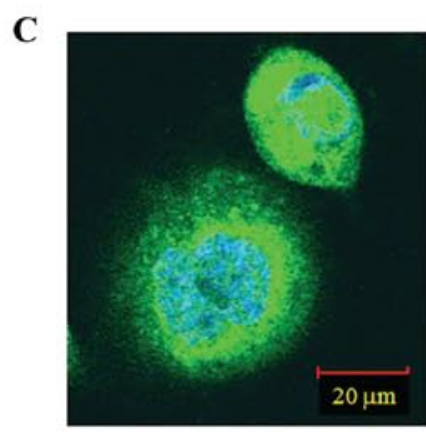

Control
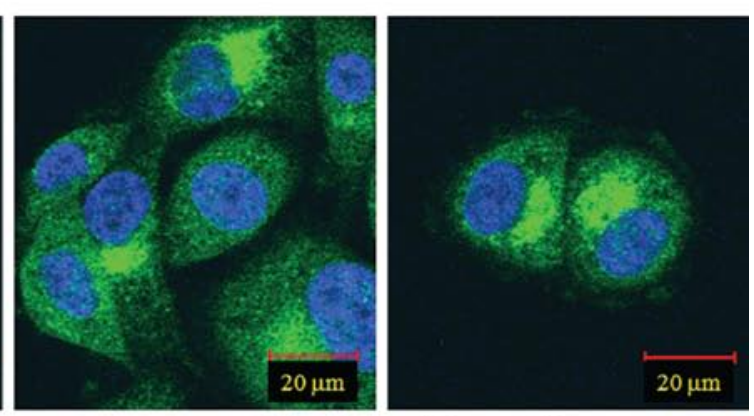

$4 \mu \mathrm{g} / \mathrm{ml}$ Stephania delavayi Diels.

$1 \mathrm{~h}$

$3 \mathrm{~h}$

D
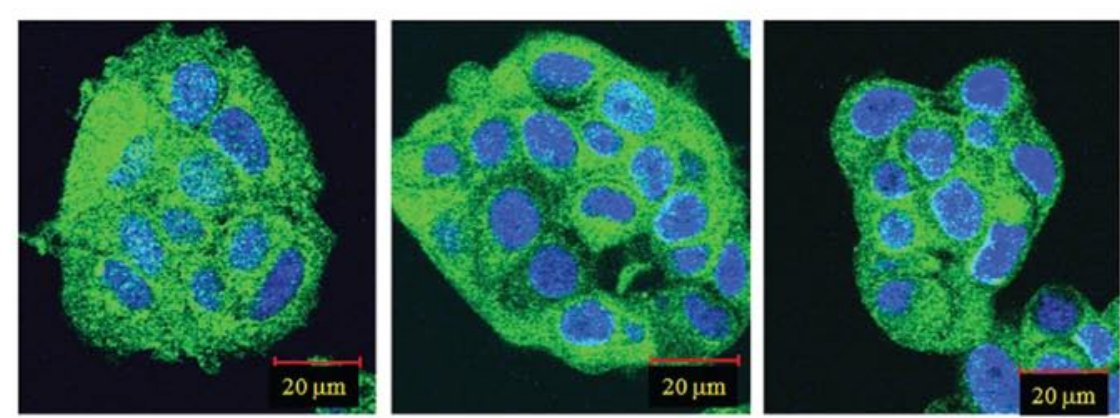

Control

$5 \mu \mathrm{g} / \mathrm{ml}$ Stephania delavayi Diels.

$1 \mathrm{~h}$

$3 \mathrm{~h}$

Figure 3. Stephania delavayi Diels. resulted in NF-kB inactivation via p38 MAPK activation/phosphorylation. (A) S. delavayi Diels. increased phosphorylated

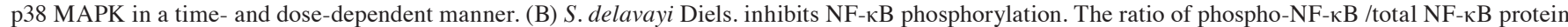
was reduced by $S$. delavayi Diels. treatment in a dose-dependent manner in MDA-MB-231 cells. In both MDA-MB-231 (C) and MCF-7 (D) cells, NF-kB protein levels significantly decreased in the nucleus following 1-h and 3-h treatment with the $\mathrm{IC}_{50}$ concentration of $S$. delavayi Diels. FITC-labeled NF- $\mathrm{kB}$ proteins were visualized in the nucleus and cytoplasm of control cells but were observed at very low levels in the nucleus of $S$. delavayi Diels.-treated cells. "p $<0.05$ and $^{* * *} \mathrm{p}<0.001$ compared to control (Tukey's studentized range test). 


\section{A MDA-MB-231}
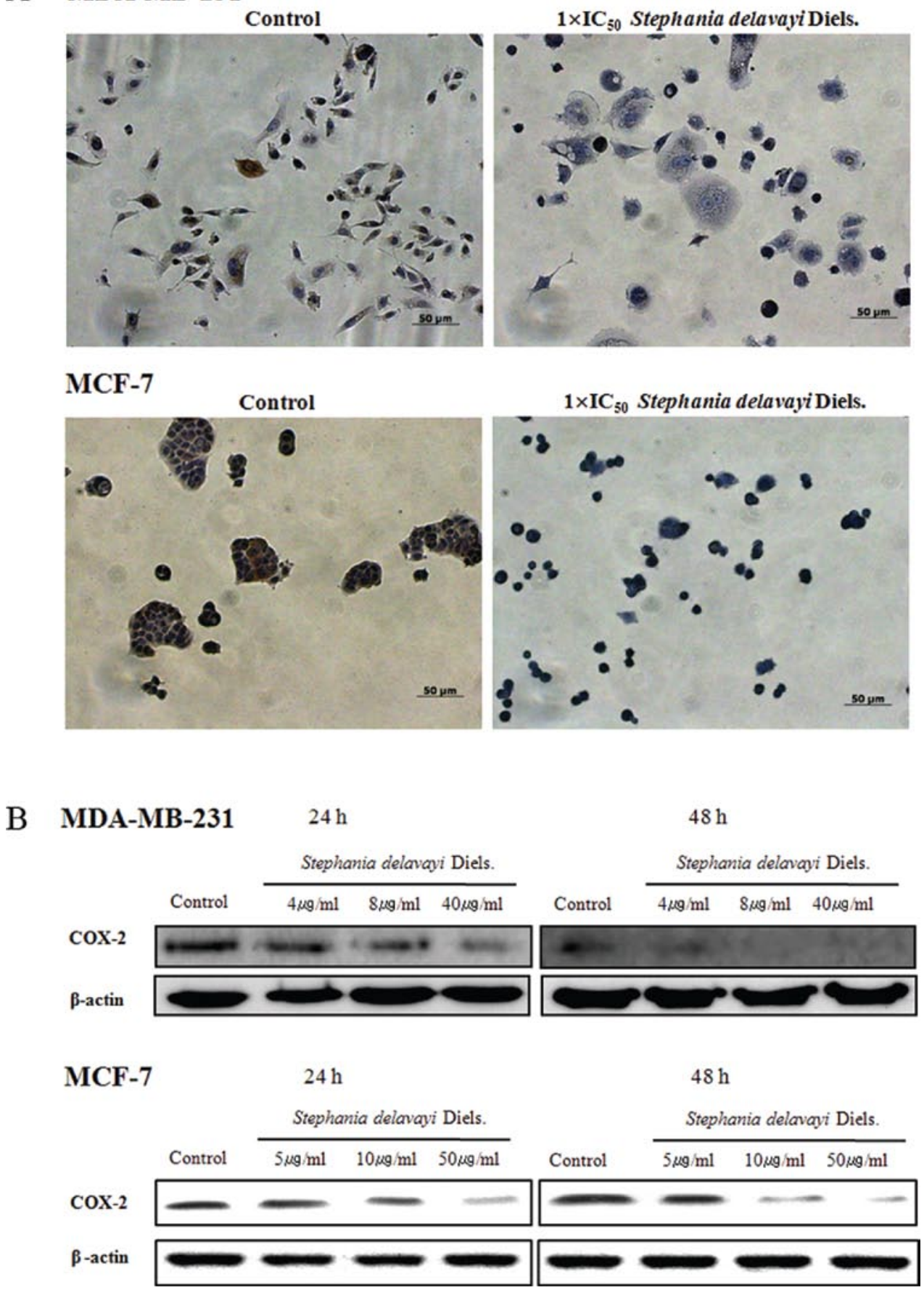

Figure 4. Inhibition of COX-2 expression by Stephania delavayi Diels. (A) Immunocytochemical analysis using a COX-2 antibody. Dark brown color represents COX-2 protein in the cytoplasm; nuclei are stained blue. COX-2 protein expression was dramatically decreased by $S$. delavayi Diels. treatment in both MDA-MB-231 and MCF-7 cells. (B) Western blot analysis using a COX-2 antibody. In both MDA-MB-231 and MCF-7 cells, S. delavayi Diels. decreased COX-2 levels in a dose- and time-dependent manner.

MAPK was detected beginning at $45 \mathrm{~min}$ in both MDA-MB231 and MCF-7 cells treated respectively with 40 and with $10 \mu \mathrm{g} / \mathrm{ml} \mathrm{S}$. delavayi Diels.; phosphorylation was further increased after 45 and $60 \mathrm{~min}$ in both MDA-MB-231 and MCF-7 cells (Fig. 3A). Activation of p38 MAPK by S. delavayi Diels. was both dose- and time-dependent.

$S$. delavayi Diels. also decreased $\mathrm{NF}-\kappa \mathrm{B}$ phosphorylation in a dose- and time-dependent manner (Fig. 3B). NF- $\kappa \mathrm{B}$ phosphorylation is required for entry into the nucleus, where it functions as a transcription factor; thus, nuclear translocation of NF- $\mathrm{BB}$ was investigated in MDA-MB-231 and in MCF-7 using an immunofluorescence assay. We found that $S$. delavayi Diels. inhibited NF- $\kappa$ B nuclear translocation (Fig. $3 \mathrm{C}$ and D).

From these observations, we conclude that the $N F-\kappa B$ pathway is an important target of $S$. delavayi Diels. in the induction of cancer cell death.

S. delavayi Diels. negatively regulates $C O X-2$ expression. COX-2 is activated in inflammation and by precancerous and cancerous tissues, and the COX-2 inhibitor sodium salicylate 


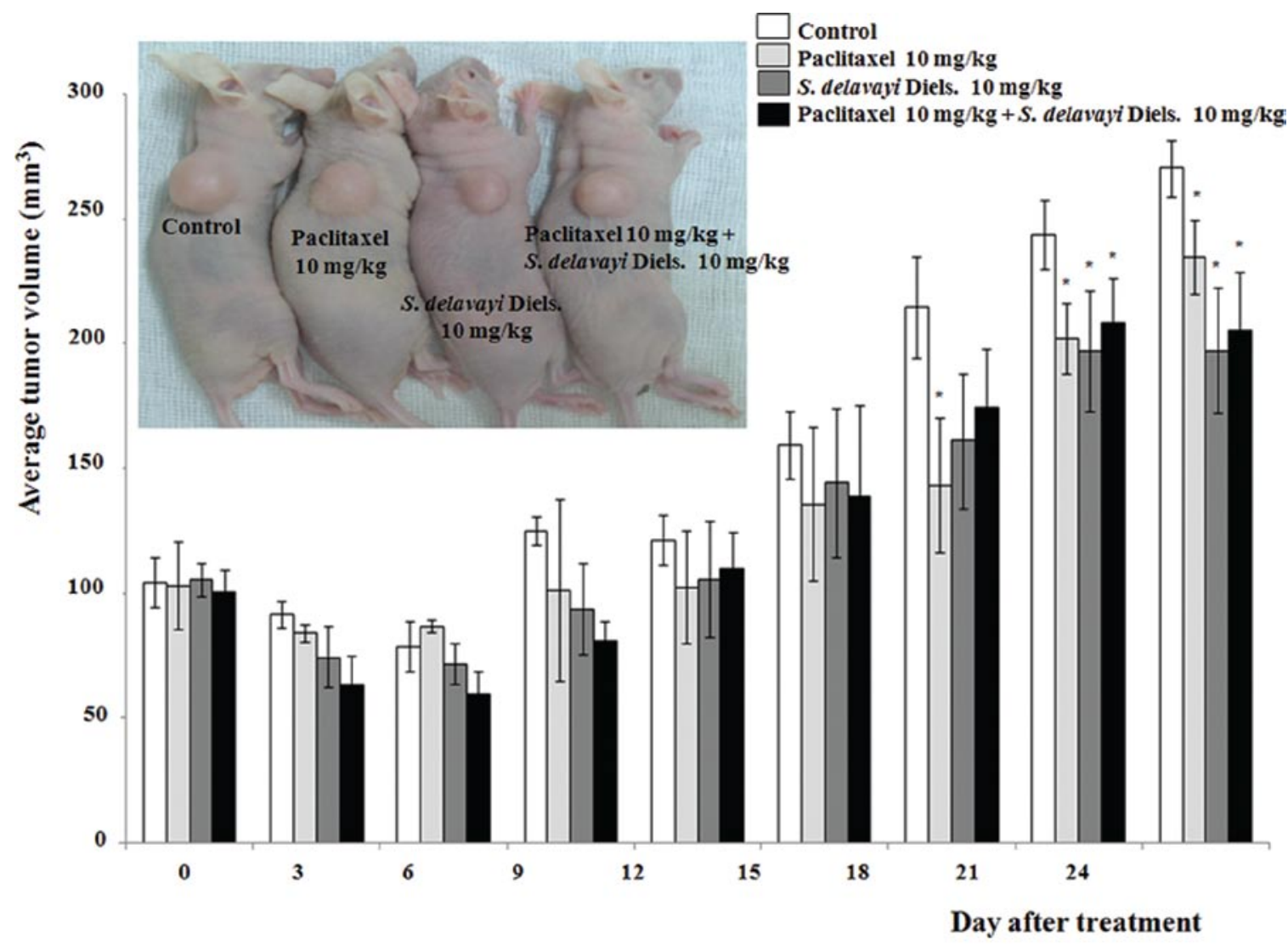

Figure 5. Stephania delavayi Diels. inhibits cancer cell growth in a mouse xenograft model. After 21 days, the mean tumor volumes of treated groups were smaller than that of the control group. S. delavayi Diels. inhibited tumor growth to an extent similar to that of paclitaxel.

is an anticancer drug candidate $(25,26)$. For this reason, we hypothesized that COX-2 is a potential target of $S$. delavayi Diels. Immunocytochemical analysis was carried out to determine the effect of S. delavayi Diels. on COX-2 expression in MDA-MB-231 and MCF-7 cells. We found that COX-2 expression was lower in S. delavayi Diels.-treated cells than in control cells (Fig. 4A). Quantitative Western blot analysis showed that $S$.delavayi Diels. reduced COX-2 protein expression in a dose- and time-dependent manner (Fig. 4B). In MDA-MB231 cells, a $24-\mathrm{h}$ treatment with $4 \mu \mathrm{g} / \mathrm{ml}$ S. delavayi Diels. reduced COX-2 expression by $\sim 50 \%$, and a 48 -h treatment with $40 \mu \mathrm{g} / \mathrm{ml}$ extract completely abolished COX-2 protein expression. A similar pattern of COX-2 expression was observed in S. delavayi Diels.-treated MCF-7 cells. These results suggest that $S$. delavayi Diels. blocks COX-2 expression by inhibiting NF- $\mathrm{\kappa B}$ phosphorylation and blocking nuclear translocation.

Since $S$. delavayi Diels. activated p38 MAPK phosphorylation and inhibited both NF- $\mathrm{kB}$ phosphorylation and COX-2 expression, the primary pathway targeted by $S$. delavayi Diels. is likely to be the $\mathrm{p} 38 \mathrm{MAPK} / \mathrm{NF}-\mathrm{\kappa B} / \mathrm{COX}-2$ pathway.

\section{S. delavayi Diels. inhibits cancer cell growth in a mouse} xenograft model. To further assess the properties of $S$. delavayi Diels., we used a mouse xenograft model to directly test its antitumor effects. After 21 days of treatment, the mean tumor volumes of all treated groups were lower than that of the control. S. delavayi Diels. inhibited tumor growth to an extent similar to paclitaxel (Fig. 5). In addition, oral administration of $S$. delavayi Diels. (50 mg/kg/day for 7 days) produced no evidence of toxicity, suggesting that this compound may be used safely (data not shown) (14). No differences in liver function tests, including complete blood cell count and serum enzyme levels, were observed between the drug treatment groups and the control group, and no histopathological changes were observed in any group. Taken together, our findings suggest that $S$. delavayi Diels. is a promising anticancer drug candidate that has a broad pharmaceutical range.

\section{Discussion}

Although epidemiologic studies have reported that vegetablebased diets decrease both the incidence and morbidity of cancer, the mechanisms of action are unclear and are therefore under investigation. For instance, Nexrutine, a herbal extract derived from Phellodendron amurense, has been investigated for its effects against prostate cancer $(27,28)$. Our group is particularly interested in herbs used in traditional East Asian medicine, and S. delavayi Diels. has long been used as an anti-inflammatory and analgesic therapy in China. There are many obstacles in developing a plant extract as a cancer therapy. For example, identifying the active components and their mechanisms of action is difficult because plant extracts are complex, sometimes containing hundreds of compounds. However, to advance the use of botanicals as cancer preventive agents, it is necessary to evaluate their ability to inhibit cancer cell proliferation and to characterize their mechanism of action.

Our results demonstrate that $S$. delavayi Diels. effectively inhibits proliferation of MDA-MB-231 and MCF-7 by inducing 
cell death. We found that $S$. delavayi Diels. induces p38 MAPK phosphorylation, down-regulates NF- $\mathrm{KB}$ phosphorylation, suppresses NF- $\mathrm{KB}$ nuclear translocation, and decreases protein expression of the downstream target COX-2. The $\mathrm{NF}-\kappa \mathrm{B}$ signaling pathway promotes tumorigenesis and progression (3) by inhibiting apoptosis (4) and inducing G1/S phase transition (5). It is controversial because the effect (i.e., activation or inactivation) of activated $\mathrm{p} 38$ MAPK on its downstream target NF- $\mathrm{KB}$ depends on cell type, environmental conditions, and the substance activating p38 MAPK $(23-25,29)$. However S. delavayi Diels. appears clearly to prevent carcinogenesis and tumor progression by inactivating NF- $\mathrm{\kappa B}$ similar to sodium salicylate which induces apoptosis through p38 MAPK phosphorylation/NF- $\mathrm{KB}$ inactivation (25).

NF- $\mathrm{kB}$ activation produces differential effects according to the cell phenotype. NF- $\kappa \mathrm{B}$ activation inhibits apoptosis $(30,31)$ and apoptosis-related protein-3 which changes during development and inflammation (32), and suppresses TNF- $\alpha$ induced apoptosis by inducing transcription of $\mathrm{Bcl}-2$, an inhibitor of apoptosis, and TNF receptor-associated factor 1 and 2 (33-35). However, NF- $\kappa \mathrm{B}$ activation can also stimulate apoptosis, as evidenced by doxorubicin-mediated induction of cell death through IкB degradation in N-type neuroblastoma cells (36) and p53-mediated apoptosis through NF- $\mathrm{BB}$ activation (37).

Many signaling pathways modulate the phosphorylation of the RelA/p65 subunit of NF- $\kappa$ B. For instance, p38 MAPK attenuates the effects of NF- $\mathrm{BB}$, thereby suppressing Fas expression (38). In addition, GSK-3 $\beta$-regulated p65 phosphorylation at Ser468 enhances its transactivation potential (39), JNK down-regulates NF- $\mathrm{KB}$ phosphorylation (40), and protein kinase A induction of p65 phosphorylation at Ser276 regulates DNA binding and oligomerization (41). We found that phosphorylation of p38 MAPK changed in a dose- and time-dependent manner after $S$. delavayi Diels. treatment but Akt and JNK phosphorylation were not affected. In addition, NF- $\kappa B$ phosphorylation decreased in a dose-dependent manner beginning at $60 \mathrm{~min}$ (Fig. 2B). These results suggest crosstalk between NF- $\mathrm{KB}$ and $\mathrm{p} 38$, as well as the dephosphorylation of NF- $\kappa B$ by p38 MAPK. However, other pathways that downregulate NF- $\kappa$ B phosphorylation, including GSK-3 $\beta$, c-raf, protein kinase A, phosphatase and tensin homolog, and signaling cascades upstream of p38 MAPK require further study. We presented evidence of the effect of $S$. delavayi Diels. on MDA-MB-231 and MCF-7 cells; however, S. delavayi Diels. requires further evaluation in additional cancer cell lines due to the complex effects of NF-кB.

Our results demonstrate that $S$. delavayi Diels. induces cell death primarily by increasing p38 MAPK phosphorylation, thereby suppressing NF- $\kappa \mathrm{B}-$ mediated transcription of COX-2. Through these processes, $S$. delavayi Diels. induced apoptosis to inhibit cell proliferation in MDA-MB-231 and MCF-7 cells. $S$. delavayi Diels. appears to effectively target a relatively specific pathway, and its use has been reported as safe (14), with relatively low toxicity compared to small molecule inhibitors of COX-2 such as celecoxib, which has numerous side effects including gastrointestinal bleeding (42). Its long history of use in traditional Chinese medicine also provides evidence for its safety.

In the present study, we showed that $S$. delavayi Diels. acts on the p38 MAPK and NF- $\mathrm{kB}$ pathways in vitro and inhibits cancer cell growth in an animal model. The use of $S$. delavayi Diels. as an anticancer drug must be validated and characterized in more detail. Nevertheless, our current knowledge of its mechanism of action, toxicity, and efficacy indicate that S. delavayi Diels. has great therapeutic potential.

\section{Acknowledgements}

This study was supported by grants from the Ministry of Education, Science and Technology (MEST) of Korea to the Korea Institute of Oriental Medicine (G07080, K08141), from BioGreen 21 (\#20070303034044), and partially from the National Cancer Center (NCC-1110060).

\section{References}

1. Cano E and Mahadevan LC: Parallel signal processing among mammalian MAPKs. Trends Biochem Sci 20: 117-122, 1995.

2. Herlaar E and Brown Z: p38MAPK signaling cascades in inflammatory disease. Mol Med Today 5: 439-447, 1999.

3. Luo JL, Kamata H and Karin M: IKK/NF-kappaB signaling: balancing life and death, a new approach to cancer therapy. J Clin Invest 115: 2625-2632, 2005.

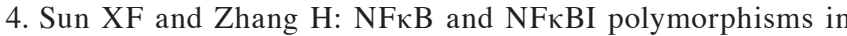
relation to susceptibility of tumour and other diseases. Histol Histophatol 22: 1387-1398, 2007.

5. Monks NR, Biswas DK and Pardee AB: Blocking anti-apoptosis as a strategy for cancer chemotherapy: NF-kappaB as a target. J Cell Biochem 92: 646-650, 2004.

6. St-Germain ME, Gagnon V, Parent S and Asselin E: Regulation of COX-2 protein expression by Akt in endometrial cancer cells is mediated through NF-kappaB/IkappaB pathway. Mol Cancer 3: 7, 2004.

7. Monks NR and Pardee AB: Targeting the NF-kappaB pathway in estrogen receptor negative MDA-MB-231 breast cancer cells using small inhibitory RNAs. J Cell Biochem 98: 221-233, 2006.

8. Jang BC, Sanchez T, Schaefers HJ, et al: Serum withdrawalinduced post-transcriptional stabilization of cyclooxygenase-2 mRNA in MDA-MB-231 mammary carcinoma cells requires the activity of the p38 stress-activated protein kinase. J Biol Chem 275: 39507-39515, 2000.

9. Karin M, Yamamoto Y and Wang QM: The IKK NF-kappa B system: a treasure trove for drug development. Nat Rev Drug Discov 3: 17-26, 2004.

10. Orlowski RZ and Baldwin AS Jr: NF-kappaB as a therapeutic target in cancer. Trends Mol Med 8: 385-389, 2002.

11. Guttridge DC, Albanese C, Reuther JY, et al: NF-kappaB controls cell growth and differentiation through transcriptional regulation of cyclin D1. Mol Cell Biol 19: 5785-5799, 1999.

12. Dannenberg AJ, Altorki NK, Boyle J, et al: Cyclo-oxygenase 2: a pharmacological target for the prevention of cancer. Lancet Oncol 2: 544-551, 2001.

13. Thun MJ, Henley SJ and Patrono C: Non-steroidal anti-inflammatory drugs as anticancer agents: mechanistic, pharmacologic, and clinical issues. J Natl Cancer Inst 94: 252-266, 2002.

14. Park DH, Li YC, Shim J, et al: Biological safety and B cells activiation effects of Stephania delavayi Diels. Mol Cell Toxicol 5: 93-98, 2009.

15. Kikukawa Y, Okuno Y, Tatetsu H, et al: Induction of cell cycle arrest and apoptosis in myeloma cells by cepharanthine, a biscoclaurine alkaloid. Int J Oncol 33: 807-814, 2008.

16. Meng LH, Zhang H, Hayward L, et al: Tetrandrine induces early G1 arrest in human colon carcinoma cells by down-regulating the activity and inducing the degradation of G1-S-specific cyclin-dependent kinases and by inducing p53 and p $21^{\mathrm{Cip} 1}$. Cancer Res 64: 9086-9092, 2004.

17. Yasukawa K, Akasu M, Takeuchi M, et al: Bisbenzylisoquinoline alkaloids inhibit tumor promotion by 12-O-tetradecanoylphorbol13 -acetate in two-stage carcinogenesis in mouse skin. Oncology 50: 137-140, 1993.

18. DiPaola RS, Zhang H, Lambert GH, et al: Clinical and biologic activity of an estrogenic herbal combination (PC-SPES) in prostate cancer. N Engl J Med 339: 785-791, 1998. 
19. Halicka H, Ardelt B, Juan G, et al: Apoptosis and cell cycle effects induced by extracts of the Chinese herbal preparation PC SPES. Int J Oncol 11: 437-448, 1997.

20. Serrano MJ, Sanchez-Rovira P, Algarra I, et al: Evaluation of a gemcitabine-doxorubicin-paclitaxel combination schedule through flow cytometry assessment of apoptosis extent induced in human breast cancer cell lines. Jpn J Cancer Res 93: 559-566, 2002.

21. Merlin JL, Barberi-Heyob M and Bachman N: In vitro comparative evaluation of trastuzumab (Herceptin ${ }^{\circledR}$ ) combined with paclitaxe $\left(\right.$ Taxol $^{\circledR}$ ) or docetaxel (Taxotere ${ }^{\circledR}$ ) in HER2-expressing human breast cancer cell lines. Ann Oncol 13: 1743-1748, 2002.

22. Tsatsanis C, Androulidaki A, Venihaki M, et al: Signalling networks regulating cyclooxygenase-2. Int J Biochem Cell Biol 38: 1654-1661, 2006.

23. Sakai N, Wada T, Furuichi K, et al: p38MAPK phosphorylation and NF- $\mathrm{KB}$ activation in human crescentic glomerulonephritis. Nephrol Dial Transplant 17: 998-1004, 2002.

24. Alpert D, Schwenger P, Han J, et al: Cell stress and MKK6bmediated p38MAP kinase activation inhibit tumor necrosis factor-induced I $\kappa \mathrm{B}$ phosphorylation and NF- $\kappa \mathrm{B}$ activation. J Biol Chem 274: 22176-22183, 1999.

25. Schwenger P, Bellosta P, Vietor I, et al: Sodium salicylate induces apoptosis via 38 mitogen-activated protein kinase but inhibits tumor necrosis factor-induced c-Jun N-terminal kinase/ stress-activated protein kinase activation. Proc Natl Acad Sci USA 94: 2869-2873, 1997.

26. Kwon KS and Chae HJ: Sodium salicylate inhibits expression of COX-2 through suppression of ERK and subsequent NF- $\kappa$ B activation in rat ventricular cardiomyocytes. Arch Pharm Res 26: 545-553, 2003

27. Kumar AP, Bhaskaran S, Ganapathy M, et al: Akt/cAMPresponsive element binding protein/cyclin D1 network: a novel target for prostate cancer inhibition in transgenic adenocarcinoma of mouse prostate model mediated by Nexrutine, a Phellodendron amurense bark extract. Clin Cancer Res 13: 2784-2794, 2007.

28. Ghosh R, Garcia GE, Crosby K, et al: Regulation of Cox-2 by cyclic AMP response element binding protein in prostate cancer: potential role for nexrutine. Neoplasia 9: 893-899, 2007

29. Goebeler M, Gillitzer R, Kilian K, et al: Multiple signaling pathways regulate NF- $\mathrm{KB}$-dependent transcription of the monocyte chemoattractant protein-1 gene in primary endothelial cells. Blood 97: 46-55, 2001.

30. van Hogerlinden M, Rozell BL and Ahrlund-Richter L, et al: Squamous cell carcinomas and increased apoptosis in skin with inhibited Rel/nuclear factor-kappaB signaling. Cancer Res 59: 3299-3303, 1999.
31. Miyamoto S, Maki M, Schmitt MJ, et al: Tumor necrosis factor alpha-induced phosphorylation of I kappa B alpha is a signal for its degradation but not dissociation from NF-kappaB. Proc Natl Acad Sci USA 91: 12740-12744, 1994

32. Yang G, Yu F, Fu H, et al: Identification of the distinct promoters for the two transcripts of apoptosis related protein 3 and their transcriptional regulation by NFAT and NFkappaB. Mol Cell Biochem 302: 187-194, 2007.

33. Herrmann JL, Beham AW, Sarkiss M, et al: Bcl-2 suppresses apoptosis resulting from disruption of the NF-kappaB survival pathway. Exp Cell Res 237: 101-109, 1997

34. Notarbartolo M, Poma P, Perri D, et al: Antitumor effects of curcumin, alone or in combination with cisplatin or doxorubicin, on human hepatic cancer cells. Analysis of their possible relationship to changes in NF- $\mathrm{NB}$ activation levels and in IAP gene expression. Cancer Lett 224: 53-65, 2005.

35. Wang CY, Mayo MW, Korneluk RG, et al: NF-kappaB antiapoptosis: induction of TRAF1 and TRAF2 and c-IAP1 and c-IAP2 to suppress caspase- 8 activation. Science 281: 1680-1683, 1998.

36. Bian X, McAllister-Lucas LM, Shao F, et al: NF-kappaB activation mediates doxorubicin-induced cell death in N-type neuroblastoma cells. J Biol Chem 276: 48921-48929, 2001.

37. Ryan KM, Ernst MK, Rice NR, et al: Role of NF-kappaB in p53-mediated programmed cell death. Nature 404: 892-897, 2000.

38. Ivanov VN and Ronai Z: Down-regulation of tumor necrosis factor alpha expression by activating transcription factor 2 increases UVC-induced apoptosis of late-stage melanoma cells. J Biol Chem 274: 14079-14089, 1999.

39. Schwabe RF and Brenner DA: Role of glycogen synthase kinase-3 in TNF-alpha-induced NF-kappaB activation and apoptosis in hepatocytes. Am J Physiol Gastrointest Liver Physiol 283: G204-G211, 2002.

40. Park MK, Hwang SY, Kim JO, et al: NS398 inhibits the growth of Hep3B human hepatocellular carcinoma cells via caspaseindependent apoptosis. Mol Cells 17: 45-50, 2004.

41. Zhong H, SuYang H, Erdjument-Bromage H, et al: The transcriptional activity of NF-kappaB is regulated by the IkappaB-associated PKAc subunit through a cyclic AMPindependent mechanism. Cell 89: 413-424, 1997.

42. Chan FK, Hung LC, Suen BY, et al: Celecoxib versus diclofenac and omeprazole in reducing the risk of recurrent ulcer bleeding in patients with arthritis. N Engl J Med 347: 2104-2110, 2002. 